Linguistik Terapan 17 (1) (2020): 43-58

Jurnal Linguistik Terapan Pascasarjana

Available online

http://jurnal.unimed.ac.id/2020/index.php/JLT-Unimed

\title{
ECONOMICS STUDENTS' PERCEPTION, ATITUDE AND MOTIVATION TOWARD LEARNING ENGLISH LANGUAGE
}

\author{
Rahmania \\ Anni Holila Pulungan \\ I Wayan Dirgeyasa \\ English Applied Linguistics Program \\ Postgraduate Program-Universitas Negeri Medan
}

Diterima Desember 2020; Disetujui Februari 2020; Dipublikasikan April 2020

\begin{abstract}
This study aimed (1) to describe the perception, attitude and motivation of Economics students in learning English. (2) to describe level of perception, the level of attitude and level of motivation of Economics students in learning English.(3) to reason why the Economics students realize such perception, attitude and motivation in learning English as the ways they are. This qualitative study was conducted at the first year of Economics students. The sources of data of this study were 58 students from two classes. The data were collected by share questionnaire and interviews then were analyzed using Interactive Models. The result showed that (1) the students perceive the important of English for his/her study and future work and students offer the general abstract statement of the important of English. They have positive attitude and negative attitudes and integrative instrumental, intrinsic and extrinsic motivation; (2) level of perception of Economics students were 485 highly positive, $33 \%$ positive and $19 \%$ negative, then the level of attitude in the level of receiving (78\%), valuing (64\%), internalizing values $(63 \%)$, responding (50\%) and organizing (43\%). The level of motivation was high. (3)some reason of students realized their perception were work, study, promote economy syariah language policy and lack of skill. For reason of students realized their attitudes were economical factor, ethnicity, language policy, occupation and listen the music, three reasons of students realized their motivation were the physical condition of class, lecturer and method of teaching.
\end{abstract}

Keywords: English, Learning, Perception, Attitude, Motivation.

How to Cite: Rahmania (2020). Economics Students' Perception, Attitude and Motivation toward Learning English Language. Jurnal Linguistik Terapan Pascasarjana Unimed.17 (1) : 43-58.

ISSN 0216-5139 


\section{INTRODUCTION}

In this era, English seems to be one of the major players of the global village. Today English is used as an international language in diplomacy, international trade, tourism, international media, air-traffic control, pop music industry, technology, economic and etc. Skill in English language is a great need to survive in the environment where the language is a necessary. As Alptekin (2002) stated that given the lingua franca status of English, it is clear that much of the world needs and uses English for Instrumental reasons such as professional contact, academics studies and commercial pursuits. It is considered the most significant and functional language for the technological and scientific development. Especially for Economics students who will find more word and knowledge of Economy in English word. They will be more competence when they understand English language. The improvement of students' competency in English is based on the lecturer who teaches them the English course. However, in order to boost learners' skill in English. Especially for undergraduate students who are not majoring in English. Every lecture would encounter some relevant questions: "Where should we start?", What should we do to involve the students in classroom activities and then they will practice the English skills in all aspects possible?", "Even though the lecture has tried their best, why do most of them seem to lack the intended interesting in learning?" To answer all the questions, it is necessary for the lecture to first understand attitude and motivation toward learning English of the courses' learners. This way, the instructors will be able to re-design the course or even adjust activities in certain classroom so that it can increase the students' stimulation and enhance the learning atmosphere. Furthermore, once students feel encouraged, their viewpoint toward learning English will finally become more positive. Prapphal (2001) suggest that increase the students' motivation toward learning the language is another way to help the students achieve their goals in learning language. In Indonesian, English teach as a foreign language. Learning a language is influenced by a variety of factors. Two of the most important of which are the learner's attitude and perception toward the target language. Different perceptions of language skills and language learning 
can have an impact on students' motivation to study languages (e.g. Csizér and Kormos 2009). Furthermorebesides the intellectual perspective, the nature of language learning has psychological and social aspects and depends primarily on the learners' motivation and attitude to learning the target language (Padwick, 2010). The ability of students to master a second language is not only influenced by the mental competence or language skills but also on the students' attitudes and perceptions toward the target language (Abidin, Majid and Hanan, 2012). They also advocated that attitude concept could enhance the process of language learning, influencing the nature of student's behaviours and beliefs toward the other language, its culture, and community, and this will identify their tendency to acquire that language. The motivation of the language learners often related with whom and where the language learner is. The community and habit will affect the students in learning language. Therefore, the student ability in mastering a language is determined by their motivation which comes from their perception and attitude toward learning language. IAIN Lhokseumawe is a campus where located in Aceh. It is a unique, because Aceh has certain culture and community with different belief of law and other. Positive and negative attitude is based on the perception of an individual toward certain objects or matters. The input of experiences which get by observation will make a belief that will influence the attitude of an individual for something. In this case the perception, attitude and motivation defined in learning English language for Economics students.

Moreover as the preliminary data, the researcher did a short interview with the lecturer who teachs the Economics students in State Islamic Institute of Lhokseumawe and a students of Economics major. Based on the interview, it can be concluded that the Economics students of IAIN Lhokseumawe are passive in the learning process due to their difficulty to respond in English. The lecturer had to share what the important of learning English although they are not an English major student, but the atmosphere of teaching learning still passively. So far, it was stated that research found variety of perception, positive and negative attitude and high 1 motivation of students in learning English. It was seen from the assumption of the language, and students interesting in learning English. In 
contrast, the study also showed the different fact beside positive apreciation learning English,they are few students still lack of motivaton and engage the teaching strategy very low. Based on some explanation above, it was stated that the study about perception, attitude and motivation were the current issues which were still controversial regarding to the recent research findings from several research where come from several countries. It meant the study was acceptable too research futher.

From the definitions above, the writer concludes that all of them have certain things in common. All the definitions describe perception as the process or phenomenon by which a person perceives any object and interprets it. This involves our five sense organs and the brain, which help in interpreting and organizing the whole process. Thus, all the definitions commonly define "Perception" as the process in which an individual receives information through the sense organs. The incoming stimuli interact with the stored information in brain (memory) to give rise to perception. It is the process by which an individual interprets various stimuli received and forms a picture of the world. The stimuli are received through the sense organs namely eyes, ears, nose, mouth and skin andare organized by brain. It is then stored as information. While doing so the individual brain colours and tags the information using its own logic and previous memory and experience, if any. Perception is thus based on assumptions about the construction of reality. Each individual is believed to develop a restricted set of perceptions through his/her unique dealings with the environment to handle the unlimited variety of possible sensory images which s/he receives. So, perception is a learned act of constructing reality to fit ones assumptions about it. The reality of the world and everything that surrounds is merely the perception of the individual. Therefore, there is a possibility that different individuals perceive different realities of a single event or object. Based on the theory of Jalkanen and Talass above it also can take the factors that affecting the perception are experience, study and work. The student can get such perception of learning English because of the experience that she got, the students who had bored in learning English in their junior high school will get negative perception toward 
learning when she/he at senior school. The students who want get a good schore for their English leason will affect their perception of learning English. The students who want geta job that need English for requirement would have positive perception toward learning English. This research concern on perception, attitude and motivation of Economics students in State Institute Islamic College of Lhokseumawe where place in Aceh. In this twenty first century there is a great need for every person to master the English language for communication purpose. English language has become a basic for students in learning and job seekers in this increasingly globalised world. The important medium to communicate among the people in various fields, such as career, academic, and business right now uses English Language. It indicated that the language was declared as the international language for various purposes, which connected the people whole over the world. Consequently, skill in English language is a great need, especially the academic students from Economics major in order to survive in the environment where the language is a necessary in academic and job seeker after graduated from the university. An Economics student must be aware how the English is a need for their learning process that will influence for future after graduated. After did a short interview with the lecture who teaches them. The lecture declared that student still passive in teaching learning process. It indicates teaching learning process not affective and the students less confident in English class. Based on the research problem in chapter one, the Economics students problem in learning English have three problems namely: (1) What the perception, attitude and motivation are found of Economics students in learning English; What are the level of perception, level of attitude and level of motivation of Economics students in learning English; and Why are the Economics students have such perception, attitudes and motivation. The research problem number one purposed to find out the perception of Econonomics students, the theory which used to answer the question related to Jalkanen and Taalas (2009), then the attitudes of Economics students by used Kara's theory andthe motivation of Economics students byDornyei and Careeira theory of motivation. 


\section{METHODOLOGY}

This study conducted in descriptive qualitative design with multi case study in order to describe the perception, attitude and motivation of Economics students in learning English. Berg in his book (2007:3) stated that qualitative research thus refers to the meaning, concept, definitions, characteristic, metaphors, symbols and description things. Qualitative design attempts to describe what is going on and what data shows. Therefore, in order to understand the phenomena, the researcher elaborates the study, make it a list and present it descriptively. "Qualitative research is descriptive. The data collected take the form of words or pictures rather than numbers. The written results of the research contain quotations from the data to illustrate and substantiate the presentation. The data include interview transcripts, fieldnotes, photographs, videotapes, personal documents, memos, and other official records. In their search for understanding, qualitative researchers do not reduce the pages upon pages of narration and other data to numerical symbols.Bogdan" The data of this research were the Econonomics students' perception, attitude and motivation toward learning English consisted of utterances from interview transcripts and the answer of questionnaire. As Bogdan said "Qualitative research is descriptive, its explore the behaviours, perspective, experiences and feelings of people and emphasize the understanding of the those elements. The sources of data were first year Economics students at State Islamic College of Lhokseumawe. For source of data researcher chosen 58 Economics students, they were chosen because they were the studentswho learn English for the semester. The first year students appropriate for giving information or data of research. The data for the research are in the form of language spoken by respondents, Economics students' perceptions, attitude, and motivation and also the reason they have such perception, attitude and motivation. The data were collected through questionnaire and interview. In such studies, attitudes are typically measured using two main types of scales: either Likert Scales, where there are five response categories ranging between two extreme positions, e.g. strongly agree andstrongly disagree, or using semantic differential questions. This research used questionnaireto collect the data named. 
It was used to see the Economics students' perception, attitude and motivation and reason to have such perception, attitude and motivation in learning English language. The questionnaire consists of 30 questions which adapted from some journals. The questions are related to students' perception or leaning English, and how their attitude and motivation toward learning English. By giving questionnaire the researcher will take presentation of perception, attitude and motivation of Economics students. The presentations are positive and negative perception, positive negative attitude and high low motivation toward learning English.

\section{FINDINGS AND DISCUSSION}

The research focuses on perception, attitude and motivation of Economics students at IAIN Lhokseumawe toward learning English. The subjects of the study were two classes of students in Economics Syariah. There were 58 students had share the questionnaire and 10 students were interview to get the data of the study. Attitude is determined by the individual's beliefs about outcomes or attributes of performing behaviour. The researcher found the Economics students shown positive attitude toward learning English, like to give opinion, speak English, and enthusiastic to join English class. The students have positive emotional attitude toward learning English, but the negative emotional attitude obtained to their English class. They wish can turn the laboratory and have higher material with related to Economics.

It is in line with Alkaff (2013) whofound that most students have a positive attitude towards learning English and that they try to improve their English and to use the language even though there are a lot of demands on their time and few opportunities to practice their English. The study also reflects on the obstacles confronting the students and their suggestions to facilitate the learning process. Motivation plays a significant role in the process learning language. Motivation is one of elements of learning everything to be successful. Harmer stated that motivation is essential to success and without motivation learners will almost certainly fail to make necessary effort. 


\section{CONCLUSION}

Based on the data analysis and research findings, there are some conclusions that can be drawn as follows: The Economics students of IAIN Lhokseumawe showed that students perceive languages as important to his or her studies or future work, the student offers general or abstract statements about the importance of languages but no one of them share has experienced the usefulness of languages. Regarding the three aspect of attitude cognitive, behavioural and emotional the students show positive attitude toward learning English, in the other hand the students still feel English hard to study and they have little interest in their English class.

\section{REFERENCES}

Abidin, M., J., Z. Majid, P., A and Hanan, A.2012. EFL Students' Attitudes towards Learning English Language: The Case of Libyan Secondary School Students. Asian Social Science. Vol. 8, No. 2; February

Alptekin, C.2002. Toward Intercultural Comunicative Competence in ELT. ELT Journal, 56 (1).

Alhmali, J.2007. Student Attitudes in the Context of the Curriculum in Libyan Education in Middle and High schools. Ph.D. Thesis, University of Glasgow.

Alkaff, A. A.2013. Students' Attitudes and Perceptions towards Learning English. Arab World English Journal International Peer Reviewd Journal. ISSN: 2229-9327. AWEJ Volume.4 Number

Alzwari et. 2012. Efl Students' Attitudes towards Learning English Language: The Case of Libyan Secondary School Students. Asian Social Science. Vol. 8, No. 2

Axelrod, P.2008. Student Perspectives on Good Teaching: What history reveals. Academic Matters: The Journal of Higher Education

Biggs, J.2002. Teaching for Quality Learning at University. The Society for Research into Higher Education \& Open University Press. 
Berliner, D.2005. The near Impossibility of Testing for Teacher Quality. Journal of Teacher Education.

Bogdan, R.C and S.K Biklen.2014.Qualitative Research for Education: An Introduction to Theory and Mehod. Boston: Allyn and Bacon, Inc

Csizér, K. and Kormos, J. (2009).Motivation, Language Identity and the L2 Self. Multilingual Matters

Chaira,t P.2013.Attitudes and Motivation of Non-English Major Students Towards Learning English as a Foreign Language: A Case Study. Thaksin University, Songkhla, Thailand

Choy, S. C. \&S Troudi.2006.Perceptions of and Attitudes towards Learning English in a Malaysian College. International Journal of Teaching and Learning in Higher Education. 18(2)

Creswell,J. W.2012. Qualitative Inquiry and Research Design: Choosing among Five Approaches.Sage.

Eliwati and Maarof., N. 2017. The Students' Perception of the Strategies in the Process Approch. Internationa Journal of Education Best Practices. Vol 1, Number 1

Dörnyei, Z.2003. Attitudes, Orientations, and Motivations in Lan Learning:

Advances in Theory, Research, and Applications. In Attitudes, Orientations, and Motivations in Language Learning. The Best of Llanguage Learning Series.

De Bot, K., Lowie, W. \& Verspoor, M. 2005. Second Language Acquisition: An Advanced Resource Book. London: Routledge.

Fakeye, D. 2010. Students' Personal Variables as Correlates of Academic Achievement in English as a Second Language in Nigeria. Journal of Social Sciences, 22 (3), 205-211.

Feng.R. \& Chen, H.2009. An Analysis on the Importance of Motivation and Strategy in Postgraduates English Acquisition. English Language Teaching. 
Feng, Z.2013..A Study on the Perceptions of Secondary School Students Regarding the Form-focused and Communication-focused English Instruction. English Linguistics Research Vol. 2, No. 2

Gardner, R. C.2008. Individual Differences in Second and Foreign language Learning. In N. Van Deusen-Scholl \& N.H. Hornberger (Eds.), Encyclopedia of Language and Education, 4. (Second and Foreign Language Education).

Kara, A.2009. The Effect of a "Learning Theories Unit" on Students Attitudes towards Learning. Australian Journal of Teacher Education

Kwangsawad, T. 2017. Stakeholders' Perceptions of Effective EFL. Teachers Journal of Education, Mahasarakham University Volume 11 Number 4 October-December 2017

Miles, M. B, Huberman, A. M, dan Saldana,J. 2014. Qualitative Data Analysis, A Methods Sourcebook, Edition 3. USA: Sage Publications. Terjemahan Tjetjep Rohindi Rohidi, UI-Press.

Hosseini, S.B., Delaram, P. 2013. Language Learners'Attitudes and Beliefs: Brief Review of the Related Literature and Framework. International Journal on New Trends in Education and Their Implications October 2013 Volume: 4 Issue: 4 Article: 06 ISSN 1309-6249

Jalkanen, J. and Taalas, P. 2012. Changing Society-Changing Language Learning and Teaching Practice. The Foreign Didactics Conference (Vikipeda). Vaasa

Jiménez, P. K.2 018. Exploring Students' Perceptions about English Learning in a Public University. Universidad Pedagógica $\mathrm{y}$ Tecnológica de Colombia, Tunja, Colombia.

Padwick, A. 2010. Attitudes towards English and Varieties of English in Globalizing India. University of Groningen. Newcastle, England.

Paul, Eggen \& Kauchak, D. 2005. Educational Psychology: Windows on Classroom, Shangxi: Shangxi Normal University Press.

Prapphal, K.2001. English Proficiency of Thai Learners and Directions of English Teaching and Learningin Thailand. 
Pirhonen, H.2015. First Year Physics Students' Perceptions of Studying Foreign Languages. University of Jyväskylä Department of Languages English.

Reid, N.2003. Getting Started in Pedagogical Research in the Physical Sciences. LTSN Physical Sciences Centre, University of Hull, Hull.

Saheb, V.2014. Motivation in English as a Foreign Language Learning. University of Halmstad. Motivation.

Shahrzad, E.2016. EFL Students' Attitudes toward Learning English Language: The Case Study of Kashan University students. Curriculum \& Teaching Studies Research Article Cogent Education, 3: 1236434

Vibulphol, J.2016. Students' Motivation and Learning and Teachers' Motivational Strategies in English Classrooms in Thailand.English Language Teaching; Vol. 9, No. 4; 2016 ISSN 1916-4742 E-ISSN 19164750 Published by Canadian Center of Science and Education

Visser, M. 2008.Learning under Conditions of Hierarchy and Discipline: The Case of the German Army (1939- 1940). Learning Inquiry. 2, 127-137.

Wimolmas, R. 2013. A Survey Study of Motivation in English Language Learning of First Year Undergraduate Students at Sirindhorn International Institute of Technology (SIIT), Thammasat University. FLLT Conference Proceedings by LITU, 2(1), 904-915.

Zhang, Q. and Kim, T. 2013. Cross-Grade Analysis of Chinese Students' English Learning Motivation: a Mixed Methods Study. Asia Pacific Education Review 14 (4), 615-627. 